\section{RISK MANAGEMENT IMPLEMENTATION MODEL IN MODERATING RISK RELATIONSHIP BASED ON INTERNAL AUDIT}

\author{
Muammar Khaddafi ${ }^{1}$, Mohd Heikal' ${ }^{2}$, Falahuddin ${ }^{3}$ \\ ${ }^{1,2,3}$ Faculty of economic and Business Universitas Malikussaleh \\ E-mail: khaddafi@unimal.ac.id
}

\begin{abstract}
This study aims to examine and analyze the influence of the Internal Audit Position on the Success of Risk Based Internal Audit, the influence of Top Management Commitment on the Success of Risk Based Internal Audit, the effect of Training on the Success of Risk Based Internal Audit, the Effect of Policy Framework on the Success of Risk Based Internal Audit, the Influence of the Communication Process. on the success of Risk Based Internal Audit, the Role of Risk Management Implementation in moderating the relationship between the Influence of Internal Audit Position, Top Management Commitment, Training, Policy Framework, and Communication on the Success of Risk Based Internal Audit.This research makes all inspectors who have a Functional Auditor Position Certificate at the district / city inspectorates in Aceh province as a population and sample. The results of this study indicate that the variables of internal audit position, top management commitment and application of risk management have no effect on the success of risk based internal audit. Meanwhile, training and policy framework variables have a positive and significant effect on the success of risk based internal audit. Communication variables were found to have no effect on the success of risk based internal audit.The moderating role of the risk management application variable is able to moderate the top management commitment, training and policy framework variables on the success of risk based internal audit. Meanwhile, the application of risk management does not moderate the influence variables of the internal audit position and communication variables on the success of risk based internal audit
\end{abstract}

Keywords : Risk Management, Commitment, Policy Framework and Risk Based Internal Audit

\section{INTRODUCTION}

The application of accounting standards in government institutions in several regions has met these standards so as to gain the WTP opinion. These standards require BPK-RI to plan and carry out audits. In order for BPK-RI to obtain adequate assurance, the financial statements are free from material misstatement. An examination includes assessing on a test basis, evidence supporting the amounts, and disclosures in the financial statements.

In accordance with Law No. 1 of 2004 concerning the State Treasury, Article 58 states "In order to improve performance, transparency and accountability in the management of State finances, one of the units that conducts audits / checks and is responsible for government internal supervision and implementation of local government is the Government Internal Supervisory Apparatus (APIP). "And in accordance with Article 24 paragraph 1 PP No. 79 of 2005 concerning Guidelines for the Guidance and Supervision of Regional Government Administration clearly states that the function and authority of APIP is to supervise government affairs in the regions. So the findings and opinions of the BPK indicate that the function of the District / City Inspectorate APIP is still not effective in carrying out its supervisory function.

Several studies have found that the use of risk management is positively and significantly related to banking financial performance [(Olayinka, Emoarehi, Jonah, \& Ame, 2017); (Chipa \& Wamiori, 2017); (Attar, 2014); Hestiecia, (2013)]. Good risk management is the identification and treatment of risks that lead to standardization of risk treatment in an organization (Nichita \& Vulpoi, 2016), as well as recommending that entities share entity risks with other entities (Chipa \& Wamiori, 2017). The important relevance of risk management to financial statements is disclosed by Gao \& Hsu (2016) which states that there is a positive relationship between adoption of Enterprise Risk 
Management and accounting quality ". In other words, it can be concluded that ERM correlates with an increase in the quality of financial reports.

\section{RESEARCH METHODS}

The research design is a plan of scientific study or research in order to answer research questions or identify problems (Sekaran, 2010). This research is a causality research. Causality research is a study that examines the influence of Internal Audit Position, Top Management Commitment, Training, Policy Framework and Communication Processes on Risk Based Internal Audit by using the Application of Risk Management as an intervening.

Sekaran (2010) states that to overcome this, two types of testing are needed, namely a test of validity and a test of reliability which is used to test the seriousness of the respondent's answer.In this study, the analytical method used to test the research hypothesis is SEM analysis of Partial Least Squares (PLS) with Warp PLS which is an indeterminacy factor in a powerful analysis method because it does not assume that the data must be measured with a certain scale, the number of samples is small or large. Warp Partial Least Squares (PLS) can also be used to confirm theory (Mahfud \& Ratmono, 2013).The path diagram is a visualization of the research conceptual framework so that it is easier to understand and learn. The formation of a path diagram must pay attention to the construct of exogenous or endogenous variables with the manifest variables of each of these latent variables.

The Moderated Structural Equation Modeling equation can be seen in the following equation:

Direct Equation (Testing H1-H6):

$\mathrm{KRBIA}=\beta 1 \mathrm{KIA}+\beta 2 \mathrm{KMP}+\beta 3 \mathrm{P}+\beta 4 \mathrm{KK}+\beta 5 \mathrm{~K}+\beta 6 \mathrm{PMR}+\mathrm{e}$

Moderation Equation (Testing H7-H11):

$\mathrm{KRBIA}=\beta 1 \mathrm{KIA}+\beta 2 \mathrm{KMP}+\beta 3 \mathrm{P}+\beta 4 \mathrm{KK}+\beta 5 \mathrm{~K}+\beta 6 \mathrm{PMR}+\beta 7 \mathrm{PMR} * \mathrm{KIA}+\beta 8 \mathrm{PMR} * \mathrm{KMP}+$ $\beta 9 \mathrm{PMR} * \mathrm{P}+\beta 10 \mathrm{PMR} * \mathrm{KK}+\beta 11 \mathrm{PMR} * \mathrm{~K}+\mathrm{e}$

Information:

$\beta 1-\beta 11$ : Regression Coefficient

KRBIA: Success Risk

KIA: Position of Internal Audit

KMP: Top Management Commitment

P: Training

KK: Policy Framework

$\mathrm{K}$ : Communication

PMR: Implementation of Risk Management

E: Error Term 


\section{ORFAI JOURNAL Multidiciplinary Output Research For Actual and International Issue}

\section{DISCUSSION}

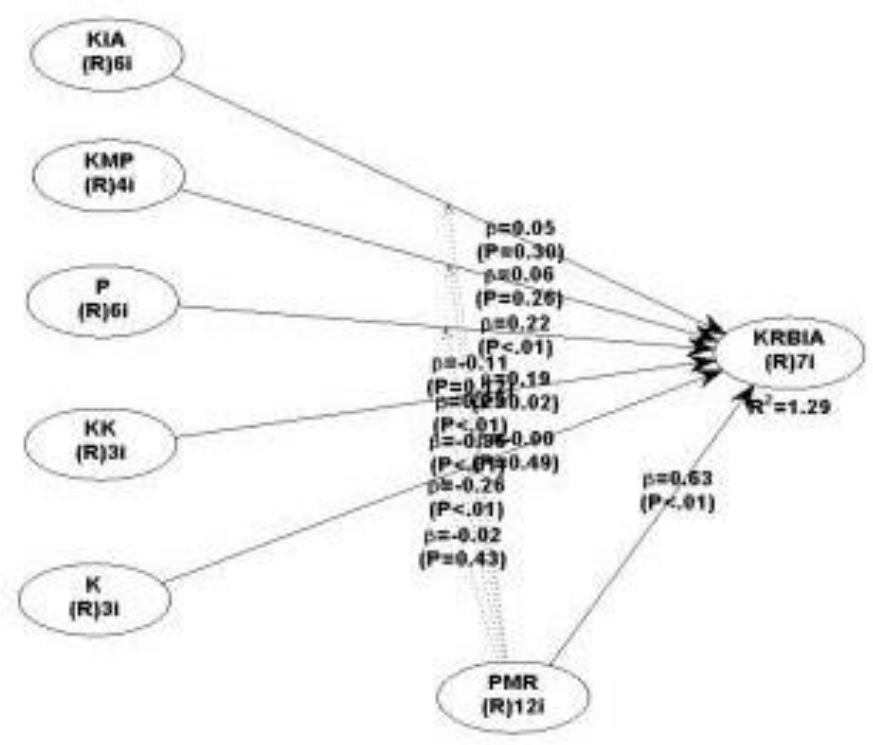

Based on Equation 4.1, it appears that KIA has a coefficient value of 0.115 . This value indicates that when the position of internal audit increases by $1 \%$, the success of risk based internal audit increases by $11.5 \%$. However, this value is not classified as statistically significant (p-value> 0.10). In other words, the research data does not support the hypothesis, so H1 is rejected, which means that the position of internal audit has no significant effect on the success of risk based internal audit.

Furthermore, KMP has a positive coefficient of 0.007 . This value indicates that when top management commitment increases by $1 \%$, the success of risk based internal audit will increase by $0.7 \%$. However, the coefficient value is not statistically significant ( $p$-value> 0.10 ). In other words, top management commitment does not have a significant effect on the success of risk based internal audit, so that $\mathrm{H} 2$ in this study is rejected.

The training variable $(\mathrm{P})$ has a coefficient value of 0.163 . This shows that when training increases by $1 \%$, the success of risk based internal audit will increase by $16.3 \%$. The coefficient value is also classified as statistically significant at the $5 \%$ level (p-value $<0.05$ ). Therefore, this research data supports $\mathrm{H} 3$, so $\mathrm{H} 3$ is accepted, meaning that training has a positive and significant effect on the success of risk based internal audit.

Furthermore, KK has a coefficient value of 0.191. This value indicates that if the policy framework increases by $1 \%$, the success of risk based internal audit will increase by $19.1 \%$. This value is also classified as statistically significant at the 5\% level (p-value <0.05). Therefore, $\mathrm{H} 4$ in this study is accepted, which means that the policy framework has a positive and significant effect on the success of risk based internal audit.

The communication $(\mathrm{K})$ has a negative coefficient of -0.028 . This value indicates that if communication increases by $1 \%$, the success of risk based internal audit will decrease by $2.8 \%$. However, this value is not classified as statistically significant (p-value>0.10). In other words, H5 in this study is rejected, meaning that communication does not have a significant effect on the success of risk based internal audit.

Furthermore, PMR has a coefficient value of 0.725 . This value indicates that when the application of risk management increases by $1 \%$, the success of risk based internal audit will increase by $72.5 \%$. This value is also classified as statistically significant at the $1 \%$ level (p-value <0.01). In 
other words, $\mathrm{H} 6$ in this study is accepted, meaning that the implementation of risk management has a positive and significant effect on the success of risk based internal audit.

Furthermore, to see the role of PMR as a moderation in the determinants of the success of risk based internal audit, it can be seen in Equation 4.2 on the parameters for variables that interact with PMR. In Equation 4.2, the PMR * KIA coefficient value is -0.108 . This value means that when the PMR increases by $1 \%$, the KIA effect on KRBIA will be $10.8 \%$. However, this value is not classified as statistically significant (p-value .0.10), so that $\mathrm{H} 7$ in this study is rejected, meaning that the effect of risk management is not able to moderate the effect of internal audit position on the success of risk based internal audit. Based on the criteria for moderating variables according to Sharma et al., (1981), the application of risk management in this relationship path is categorized as a variable predictor, meaning that it has a significant direct effect but does not have a significant effect as a moderator.

The value of the PMR * KMP coefficient is 0.226 . This value indicates that when the application of risk management increases by $1 \%$, the effect of top management commitment on the success of risk based internal audit will increase by $22.6 \%$. This value is also classified as significant at the $1 \%$ level (p-value $<0.01$ ), so that $\mathrm{H} 8$ in this study is accepted, meaning that the application of risk management is able to strengthen the influence of top management commitment to risk based internal audit. Reflecting on the moderating variable criteria proposed by Sharma et al. (1981), then the application of risk management in this relationship flow is included in the Quacy Moderator criterion, because it has a significant effect either as a predictor or moderator. Equation 4.2 also shows that KMP directly has a positive effect on KRBIA. This shows that commitment

Top management will have a positive influence on the success of risk based internal audit for all values of risk management implementation.

Furthermore, the value of the PMR $* \mathrm{P}$ coefficient is -0.356 . This value indicates that when the application of risk management increases by $1 \%$, the effect of training on the success of risk based internal audit will weaken by $35.6 \%$. This value is also classified as statistically significant at the $1 \%$ level, so that $\mathrm{H} 9$ is accepted, which means that the application of risk management is able to weaken the effect of training on the success of risk based internal audit. Training will have a negative effect on the success of risk based internal audit when the level of risk management application is above $0.615(61.5 \%)$ and will have a positive effect when the level of risk management application is below $0.615(61.5 \%)$. The value of $0.615(61.5 \%)$ is obtained from the fragment of the KRBIA $=$ $(0.219-0.356 \mathrm{PMR}) * \mathrm{P}$ with the condition $(0.219-0.356 \mathrm{PMR})=0$, then the calculation result is $\mathrm{PMR}=-0.219 /-0.356=0.615(61.5 \%)$.

Furthermore, the value of the PMR * KK coefficient is -0.261 . This value indicates that when the application of risk management increases by $1 \%$, the effect of the policy framework on the success of risk based internal audit will weaken by $26.1 \%$. In addition, this value is also classified as statistically significant at the $1 \%$ level (p-value <0.01). In other words, the application of risk management weakens the influence of the policy framework on the success of risk based internal audit, so that $\mathrm{H} 10$ is accepted. In the flow of this relationship, the variable of risk management implementation is included in the Quacy Moderator criterion, which has a significant influence both predictors and moderators (Sharma et al., 1981). The policy framework will have a negative effect when the value of risk management is above $0.743(74.3 \%)$ and will have a positive effect when the value of risk management implementation is below $0.743(74.3 \%)$. The value of $0.743(74.3 \%)$ is obtained from a piece of the equation KRBIA $=\ldots . .(0.194 \mathrm{KK}-0.261 \mathrm{PMR}) * \mathrm{KK}$ with the provisions of $0.194 \mathrm{KK}-0.261 \mathrm{PMR}=0$, resulting in a calculation of PMR $=-0.194 /-0.261=0.743(74.3 \%)$.

Furthermore, the value of the PMR $* \mathrm{~K}$ coefficient is -0.016 . This value indicates that when the application of risk management increases by $1 \%$, the effect of communication on the successful application of risk based internal audit will weaken by $1.6 \%$. However, the coefficient value is not statistically significant ( $\mathrm{p}$-value> 0.10 ), so it can be concluded that the application of risk management is not able to moderate the effect of communication on the success of risk based internal 


\section{ORFAI JOURNAL Multidiciplinary Output Research For Actual and International Issue}

audit, so H11 is rejected. In the flow of this relationship, the application of risk management is included in the predictor variable criteria, which only has a significant effect at the time as a predictor, but is not able to have a significant effect as a moderator variable.

\section{CONCLUSION}

Based on the results of the SEM-PLS analysis with WarpPLS that has been carried out, the conclusions of this study are as follows:

1. The position of the internal audit does not have a significant effect on the success of the Risk Based Internal Audit.

2. Top Management Commitment has no significant effect on the success of Risk Based Internal Audit.

3. Training has a positive and significant effect on the success of Risk Based Internal Audit.

4. The policy framework has a positive and significant effect on the success of Risk Based Internal Audit.

5. Communication has no significant effect on the success of Risk Based Internal Audit.

6. The implementation of risk management has a positive and significant effect on the success of Risk Based Internal Audit.

7. The application of risk management is unable to moderate the effect of internal audit position on the success of Risk Based Internal Audit.

8. The application of risk management moderates the effect of top management commitment on the success of Risk Based Internal Audit.

9. The application of risk management moderates the effect of training on the success of Risk Based Internal Audit.

10. The application of risk management moderates the effect of the policy framework on the success of Risk Based Internal Audit.

11. The application of risk management is unable to moderate the effect of communication on the success of Risk Based Internal Audit.

\section{SUGGESTIONS}

The suggestions that researchers can give to stakeholders are as follows:

1. The lowest average score for the internal audit position indicator is indicator 4 , so it is advisable for stakeholders at the District / City Inspectorate in Aceh Province to have a freer and more professional mental attitude in carrying out the examination.

2. The lowest average score for the indicator for top management commitment is indicator 4 , so it is advisable for regional heads in Aceh to conduct more frequent evaluation activities on the policies they have established.

3. The lowest average score for the training indicator is indicator 3, so it is recommended that stakeholders at the District / City Inspectorate in Aceh Province provide training materials related to risk management.

4. The lowest average score for the policy framework indicator is indicator 3, so it is advisable for stakeholders at the Inspectorate at the District / City in Aceh Province to continue implementing the supporting factors that can realize the implementation of risk management.

5. The lowest average score for the communication indicator is at indicator 3 , so it is recommended that stakeholders at the District / City Inspectorate in Aceh Province continue to evaluate the communication system between the parties involved in the inspection.

6. The lowest average value for the risk management implementation indicator is at the 6th indicator, so it is recommended that stakeholders at the District / City Inspectorate in Aceh Province continue to monitor the work unit (ODP) in the risk management implementation process. 
7. The lowest average score for the success indicator of Based Risk Internal Audit is indicator 6, so it is recommended that stakeholders at the District / City Inspectorate in Aceh Province analyze and predict any risks that occur from activities.

8. The variable that most influences the success of Based Risk Internal Audit is the application of risk management, so it is recommended that stakeholders at the District / City Inspectorate in Aceh Province continue to apply risk management in conducting audits, because it has a good impact on the success of Internal Based Risk. Audit.

9. It is recommended that the next researchers analyze other factors that influence the success of the Based Risk Internal Audit, with different objects, locations and analysis techniques for the sake of developments in the field of Public Accounting.

\section{REFERENCES}

Abang'a, A. O. (2017). Determinants of quality of financial reporting among semi -autonomous government agencies in Kenya. Strathmore University. Retrieved from http://suplus.strathmore.edu/handle/11071/5581

Abdullah, M. W. (2010). Pemoderasi Kompetensi Sumber Daya Manusia Terhadap Peningkatan Kualitas Laporan Keuangan Daerah Kabupaten Bone. Jurnal Ilmiah Akuntansi Peradaban, Vol. III(No. 2), 45-65.

Afiah, N. N. (2009). Implementasi Akuntansi Keuangan Pemerintah Daerah. Jakarta: Kencana Prenada Media Grup.

Afiah, N. N., \& Rahmatika, D. N. (2014). Factors Influencing The Quality Of Financial Reporting And Its Implications On Good Government Governance (Research on Local Government Indonesia). International Journal of Business, Economics and Law, 5(1), 111-121.

AIRMIC, Alarm, \& IRM. (2010). A structured approach to Enterprise Risk Management ( ERM) and the requirements of ISO 31000 Contents.

Anggriawan, F. T., \& Yudianto, I. (2018). Factors Affecting Information Quality of Local Government Financial Statement of West Bandung District, West Java Province, Indonesia. Journal of Accounting Auditing and Business, 1(1), 34-46.

Attar, D. (2014). Pengaruh penerapan manajemen risiko terhadap kinerja keuangan perbankan yang terdaftar di bursa efek indonesia 1). Jurnal Akuntansi Pascasarjana Universitas Syiah Kuala, 3(1), 10-20. https://doi.org/10.13140/RG.2.1.3589.4882

Ayub, R. D., Utama, M. S., \& Wardana, I. G. (2018). Analisis Faktor-Faktor Yang Mempengaruhi Good Governance Pada Pemerintah Provinsi Bali. E-Jurnal Ekonomi Dan Bisnis Universitas Udayana, 7(4), 987-1022.

Azlim, D., \& Usman, A. B. (2012). Pengaruh penerapan good governance dan standar akuntansi pemerintahan terhadap kualitas laporan SKPD di Kota Banda Aceh. Jurnal Akuntansi Pasca Sarjana Universitas Syiah Kuala, Vol. 1(No. 1.).

Beest, F. Van, Braam, G., \& Boelens, S. (2009). Quality of Financial Reporting: measuring qualitative characteristics. The Netherlands.

Belkaoui, A. R. (1992). Executive Compensation, Organizational Effectiveness, Social Performance And Firm Performance: An Empirical Investigation. Journal of Business Finance \& Accounting, 19(October 1988), 25-38.

Chipa, E. M., \& Wamiori, G. (2017). The effect of risk management on financial performance of insurance companies in Kenya. Imperial Journal of Interdisciplinary Research, 3(5), 259-282. https://doi.org/10.1109/ICEEE.2013.6676054

Christie, A. A. (1990). Aggregation of test statistics. An evaluation of the evidence on contracting and size hypotheses. Journal of Accounting and Economics, 12(1-3), 15-36. https://doi.org/10.1016/0165-4101(90)90039-7

Cohen, J. (2016). Enterprise Risk Management and the Financial Reporting Process: The Experiences of Audit Committee Members, CFOs, and External Auditors. Contemporary 
Accounting Research,. https://doi.org/10.1111/ijlh.12426

Cooper, D. (2006). The Impact of Management's Commitment on Employee Behavior: A Field

Study. American Society of Safety Engineers Middle East Chapter, 1(317), 7-14

COSO. (2004). Enterprise Risk Management - Integrated Framework: Executive Summary. Committee of Sponsoring Organizations of the Treadway Commission.

COSO. (2014). FAQs for COSO's Enterprise Risk Management — Integrated Framework.

Dabor, Alexander Olawumi, M. A. (2017). Adoption Of International Public Sector Accounting By Government Ministries And Agencies In Nigeria. International Journal of Marketing \& Financial Managemen, 5(5), 52-65.

Domokos, L., Nyéki, M., \& Jakovác, K. (2015). Risk Analysis and Risk Management in the Public Sector and in Public Auditing. Public Finance Quarterly 1, 1, 1-28.

Drew, M. (2007). Information risk management and compliance-expect the unexpected. $B T$ Technology Journal, 25(1), 19-29. Retrieved from http://link.springer.com/article/10.1007/s10550-007-0004-x

Drew, S. A. W., \& Kendrick, T. (2005). Risk Management: the five pillars of corporate governance. Journal of General Management, 31(2), 19-36.

Dumontier, P., \& Raffournier, B. (1998). Why Firms Comply Voluntarily With IAS: an Empirical Analysis with Swiss Data. Jurnal of International Financial Management and Accounting, 9(3), 216-245.

Eriadi, Erlina, Muda, I., \& Abdullah, S. (2018). Determinant analysis of the Quality of Local Government Financial Statements in North Sumatra With the Effectiveness of Management of Regional Property As A Mediator. International Journal of Civil Engineering and Technology (IJCIET), 9(5), 1334-1346.

Erlina, Rambe, O. S., \& Rasdianto. (2017). Akuntansi Keuangan Daerah Berbasis Akrual. Jakarta: Salemba Empat.

Erviana. (2017). Pengaruh Implementasi Sistem Informasi Manajemen Daerah dan Kegiatan Pengendalian Terhadap Kualitas Laporan Keuangan Pemerintah Daerah (Survey Pada Satuan kerja Perangkat Daerah (SKPD) Kota Palu). E Journal Katalogis, 5(4), 182-193.

Etzioni, A. (1961). A Comparative Analysis of Complex Organizations. New York: The Free Press.

Fadzil, F. H., \& Nyoto, H. (2011). Fiscal Decentralization after Implementation of Local Government Autonomy in Indonesia. World Review of Business Research, 1(2), 51-70.

Fauziah, I. (2018). SAP Stanndar Akuntansi Pemerintah (Sesuai Peraturan Pemerintah Republik Indonesia Nomor 71 Tahun 2010) (1st ed.). Jakarta: Ilmu

Gamayuni, R. R. (2017). The Effect of Internal Audit Function Effectiveness and Implementation of Accrual Based Government Accounting Standard on Financial Reporting Quality. Review of Intergrative Business \& Economics Research, 7(1), 46-58. Retrieved from http://buscompress.com/uploads/3/4/9/8/34980536/riber_7-s1_sp_h17-021_46-58.pdf

Gao, S., \& Hsu, H.-T. (2016). Enterprise Risk Management and Accounting Quality Abstract In this study we examine the role of enterprise risk management (ERM) in financial reporting quality . ERM expands internal control to form a solid conceptualization focusing more on risk. Usin. American Risk and Insurance Association (ARIA). Retrieved from http://www.aria.org/Annual_Meeting/2016/Papers/Session2/II-A/Enterprise Risk Management and Accounting Quality.pdf

Gumanti, T. A. (2002). Pilihan-pilihan akuntansi dalam aplikasi teori akuntansi positif. Jaai, 6(1), 83-101.

Hall, J. A. (2001). Sistem Informasi Akuntansi (Buku Satu). Jakarta: Salemba Empat.

Hanggraeni, D. (2015). Manajemen Risiko Perusahaan (Enterprise Risk Management) dan Good Corporate Governance. Jakarta: UI-PRESS

Hardjosoedarmo, S. (2006). Total Quality Management. Yogyakarta: ANDI. 
Harlinda. (2016). Analisis Faktor-faktor yang Mempengaruhi Kualitas Informasi Laporan Keuangan Pemerintah Daerah ( Studi Empiris pada Pemerintah Kabupaten / Kota di Provinsi Riau ). Jurnal Sorot, 11(2), 127-144.

Hestiecia, W. (2013). Manajemen Resiko dalam Implementasi Prinsip Good Corporate Governance (GCG) Dan Hubungannya Terhadap Kinerja Perusahaan (Studi Kasus PT XTEL). Jurnal Ilmiah Universitas Bakrie, 1(2), 1-2.

Holthausen, R. W., \& Leftwich, R. W. (1983). Econormcs 5 (1983) 77-117. North-Holland. Journal of Accounting and Economics, 5, 77-117.

Ijeoma, N. B., \& Oghoghomeh, T. (2014). Adoption of international public sector accounting standards in Nigeria: Expectations, benefits and challenges. Journal of Investment and Management, 3(1), 21-29. https://doi.org/10.11648/j.jim.20140301.13

Jensen, \& Meckling. (1976). Theory of the Firm: Managerial Behavior, Agency Cost and Ownership Structure. Journal of Financial Economics, 3(4), pp: 305-360.

Julita, \& Susilatri. (2018). Analysis Of Factor Affecting The Quality Of Government Financial Report Bengkalis Regency. International Journal of Scientific \& Technology Research, 7(2), 157-164.

Juran, J. M. (1992). Juran on Quality by Design: The New Steps for Planning Quality into Goods and Services. United States of Amerika: The Free Press.

Kibet, A. J. (2016). Effects of Management Commitment on Financial Performance of Private Schools : A Survey of Selected Schools in Trans-Nzoia County, Kenya. European Journal of Business and Management, 8(30), 1-5.

Kurniawan, S. (2011). BPK RI Beri Opini WDP terhadap LKPD Enam Pemerintah Kabupaten/Kota di Jabar. Siaran Pers Penyerahan LHP-LKPD TA 2010.

Kusuma, F. P., Yasa, I. N. M., \& Djayastra, I. K. (2016). Analisis Faktor-Faktor Yang Mempengaruhi Kualitas Informasi Pelaporan Keuangan pemerintah Daerah Kabupaten Jembrana. E-Jurnal Ekonomi Dan Bisnis Universitas Udayana, 5(12), 4115-4150.

Kesuma, D. P., Anwar, C., \& Darmansyah. (2017). Pengaruh Good Governance, Penerapan Standar Akuntansi Pemerintah, Sistem Pengendalian Internal Pemerintah dan Kompentensi Aparatur Pemerintah Terhadap Kualitas Laporan Keuangan Pemerintah Pada Satuan Kerja Kementerian Pariwisata. Jurnal Ilmiah WIDYA Ekonomika, 1(2), 141-146.

Kibet, A. J. (2016). Effects of Management Commitment on Financial Performance of Private Schools : A Survey of Selected Schools in Trans-Nzoia County, Kenya. European Journal of Business and Management, 8(30), 1-5.

Li, S., \& Nadeem, M. (2010). Risk Management and Internal Control ( A Case Study of China Aviation Oil Corporation Ltd). University West.

Mahfud., Solihin \& Dwi Ratmono. (2013). Analisis SEM-PLS dengan WarpPLS 3.0. Penerbit Andi, Yogyakarta.

Mahlil, \& Yahya, M. R. (2017). Pengaruh komitmen kepala daerah dan pengetahuan akuntansi terhadap kualitas laporan keuangan pemerintah daerah di provinsi aceh. Jurnal Ilmiah Mahasiswa Ekonomi AKuntansi (JIMEKA), 2(2), 21-29.

Mailoor, J. H., Sondakh, J. J., \& Gamaliel, H. (2017). Pengaruh Sistem Akuntansi Pemerintahan, Budaya Organisasi , Kinerja Aparatur Pemerintah Daerah , Peran APIP , Dan Sistem Pengendalian Intern Pemerintah Terhadap Penerapan Good Governance ( Studi Empiris Di Kabupaten Kepulauan Talaud ). Jurnal Riset Akuntansi Dan Auditing “Goodwill, ”8(2), 82-94.

Maksyur, N. V., Tanjung, A. R., \& Hariani, E. (2015). Pengaruh Kualitas Sumber Daya Manusia, Komitmen Organisasi, Sistem Pengendalian Intern, Dan Pemanfaatan Teknologi Informasi Terhadap Kualitas Laporan Keuangan. Jom Fekon, 2(2), 1-15.

Mardiasmo. (2009). Akuntabilitas Sektor Publik (IV). Yogyakarta: C.V Andi Offset.

Missonier-Piera, F. (2004). Economic determinants of multiple accounting method choices in a Swiss context. Journal of International Financial Management and Accounting, 15(2), 118-144. 
https://doi.org/10.1111/j.1467-646X.2004.00104.X

Mowday, R. T., Steers, R. M., \& Porter, L. W. (1979). The Measurement of Organizational Commitment. Journal of Vacational Behavior, 14, 224-247.

Muda, I., Harahap, A. H., Erlina, Ginting, S., Maksum, A., \& Abubakar, E. (2018). Factors of quality of financial report of local government in Indonesia. International Journal for Quality Research, 8(1), 73-86. https://doi.org/10.1088/1755-1315/

Mutiana, L., Diantimala, Y., \& Zuraida. (2017). Pengaruh sistem pengendalian intern, teknologi informasi, kualitas sumber daya manusia dan komitmen organisasi terhadap kualitas laporan keuangan. Jurnal Perspektif Ekonomi Darusaslam, 3(2), 151-167.

Meizaroh, \& Lucyanda, J. (2011). Pengaruh Corporate Governance dan Konsentrasi Kepemilikan Pada Pengungkapan Enterprise Risk Management. In Simposium Nasional Akuntansi XIV Aceh 2011. Banda Aceh.

Nelia K, M. (2015). The Effect Of Adoption Of International Public Sector Accounting Standards On Financial Reporting In The Public Sector In Kenya.

Nichita, M. E., \& Vulpoi, M. (2016). Relationship between risk and transparency in the financial statements of professional services entities. Audit Financiar, 14(137), 540. https://doi.org/10.20869/AUDITF/2016/137/540

Nugraheni, P., \& Subaweh, I. (2008). Pengaruh penerapan standar akuntansi pemerintahan terhadap kualitas laporan keuangan. Jurnal Ekonomi Bisnis, 13(1), 48-58.

Nurviasari, R., \& Riharjo, I. B. (2016). Pengaruh sistem informasi, komitmen manajemen, budaya organisasi terhadap akuntabilitas kinerja instansi pemerintah. Jurnal Imu Dan Riset Akuntansi, 5(April).

Olayinka, E., Emoarehi, E., Jonah, A., \& Ame, J. (2017). Enterprise Risk Management and Financial Performance: Evidence from Emerging Market. International Journal of Management, Accounting and EconomicsOnline) International Journal of Management, Accounting and Economics International Journal of Management, Accounting and Economics, 4(49), 937-952. Retrieved from www.ijmae.com

Onyulo, O. F. (2017). Factors Influencing Quality of Financial Reporting in Public Sector Entities in the Ministry of Environment and Natural Resources Kenya. KCA UNIVERSITY.

Opanyi, R. O. (2016). The Effect of Adoption of International Public Sector Accounting Standards on Quality of Financial Reports in Public Sector in Kenya. European Scientific Journal, 12(28), 161-187. https://doi.org/10.19044/esj.2016.v12n28p161

Peraturan Menteri Keuangan Nomor 191 Tahun. Peraturan Menteri Keuangan Republik Indonesia Nomor 191/PMK.09/2008 Tentang Penerapan Manajemen Risiko Di Lingkungan Departemen Keuangan, Menteri Keuangan § (2008). https://doi.org/10.1007/s13398-014-0173-7.2

Peraturan Menteri Keuangan Republik Indonesia Nomor 234 Tahun. Peraturan Menteri Keuangan Republik Indonesia Nomor 234/PMK.01/2015 Tentang Organisasi Dan Tata Kerja Kementerian Keuangan (2015).

Peraturan Pemerintah Nomor 24 Tahun. Peraturan Pemerintah Republik Indonesia Nomor 24 Tahun 2005 Tentang Standar Akuntansi Pemerintahan (2005). Indonesia.

Peraturan Pemerintah Nomor 58 Tahun. Peraturan Pemerintah Republik Indonesia Nomor 58 Tahun 2005 Tentang Pengelolaan Keuangan Daerah (2005). Indonesia.

Peraturan Pemerintah Nomor 60 Tahun. Peraturan Pemerintah Republik Indonesia Nomor 60 Tahun 2008 Tentang Pengendalian Intern Pemerintah (2008).

Peraturan Pemerintah Nomor 71. Pemerintah Republik Indonesia, Peraturan Pemerintah Nomor 71 Tahun 2010 tentang Standar Akuntansi Pemerintahan (2010).

Porter, L. ., Steers, R. ., Mowday, R. ., \& Boulivan, P. . (1974). Organizational Commitment, Job Satisfaction, and Turnover Among Psychiatric Technicians. Journal of Applied Psychology, 59(5), 603-609.

Purwati, A. S. (2016). Faktor-Faktor Yang Mempengaruhi Kualitas Laporan Keuangan Pada UMKM 
di Kabupaten Banyumas. Journal \& Proceeding JPFBUNSOED, 808-818.

Rachmad, A. A. (2011). Pengaruh Penerapan Corporate Governance Berbasis Karakteristik Manajerial pada kinerja Perusahaan Manufaktur. E-Jurnal Akuntansi, 2(3), 678-696.

Raharjo, E. (2007). Teori Agensi dan Teori Stewarship dalam Perspektif Akuntansi. Jurnal Fokus Ekonomi, 2(1), 37-46.

Rahman, D., Hardi, \& Diyanto, V. (2015). Pengaruh Pemanfaatan Teknologi Informasi, Penerapan Sistem Akuntansi Keuangan Daerah, Dan Penerapan Standar Akuntansi Pemerintahan Terhadap Kualitas Laporan Keuangan Daerah (Studi Empiris Pada SKPD Provinsi Riau). Jom Fekon, 2(2), 1-15.

Rahmatika, D. N. (2016). Determinant Factors Influencing The Level Of Fraud And Implication To Quality Of Financial Reporting (Research At Local Governments Indonesia). J A B E R, 14(14), 861-879.

Rachmawati, R. (2018). Model Struktural Hubungan Budaya Organisasi, Kompetensi Pengguna, Pengendalian Internal dan Kualitas Informasi Akuntansi Pemerintah Daerah. Jurnal Ilmiah Manajemen, $\operatorname{VIII}(1), 136-150$.

Ratifah, I., \& Ridwan, M. (2012). Komitmen Organisasi Memoderasi Pengaruh Sistem Akuntansi Keuangan Daerah terhadap Kualitas Laporan Keuangan. Trikonomika, 11(1), 29-39.

Rezaee, Z. (2002). Financial Statement Fraud (Prevention and Detection). New York: John Wiley $\&$ Sons, Inc.

Rezaee, Z. (2003). High-Quality Financial Reporting The Six-Legged Stool.

S, M. B. T., Taufik, T., \& Hariyani, E. (2015). Pengaruh Good Governance, Kompetensi Sumber Daya Manusia dan Sistem Pengendalian Intern Terhadap Kualitas Laporan Keuangan (Studi Empiris Pada SKPD Kota Dumai). Jom Fekon, 2(2), 1-14.

Sako, U., \& Lantowa, F. D. (2018). Pengaruh Penerapan Standar Akuntansi Pemerintahan Terhadap Kualitas Penyajian Laporan Kueangan Pada Pemerintah Kabupaten Gorontalo. Journal of Accounting Science, 2(1), 43-54.

Salancik, G. R., \& Pfeffer, J. (1977). An Examination of Need-Satisfaction Models of Job Attitudes. Administrative Science Quarterly, 22(3), 427-456.

Sari, D. (2012). Pengaruh Sistem Pengendalian Intern Pemerintah, Implementasi Standar Akuntansi Pemerintah, Penyelesaian Temuan Audit, Terhadap Kualitas Laporan Keuangan Pemerintah Daerah dan Impllikasinya Terhadap Penerapan Prinsip-Prinsip Tata Kelola Pemerntahan Yang Ba. Indonesian Journal of Economics And Business, 2(2), 116-124

Sawyer, L. B., Dittenhofer, M. A., \& Scheiner, J. H. (2003). Audit Internal (5th ed.). Jakarta: Salemba Empat..

Scoot, R. (2008). Institutions and Organization: Ideas and Interest. USA: SAGE Publication.

Sharma, S., Durand, R. M., \& Gur-Arie, O. (1981). Identification and analysis of moderator variables. Journal of marketing research, 18(3), 291-300.

Silviana. (2012). Pengaruh Komitmen Kepala Daerah Terhadap Kualitas Laporan Keuangan Pemerintah Daerah di Provinsi Jawa Barat. In Seminar NAsional Akuntansi \& Bisnis (SNAB) (pp. 862-869).

Sohidin, Witurachmi, S., \& Ariyanto, J. (2010). Rancangang Penyusunan Sistem Informasi Akuntansi Pada Pemerintah Daerah Guna Meningkatkan Good Governance dan Tata Pelaporan Yang Sesuai Dengan Standar Akuntansi Sektor Publik (Studi Kasus Di Pemerintah Kabupaten Sukuharjo. In Seminar Nasional Pendidikan Akuntansi dan Keuangan (pp. 281-306).

Song, G., \& Kemp, S. T. (2013). Does The Existence of An Enterprise Risk Management (ERM) Program Inflience The Existence of Material Weaknesses In Internal Control Over Financial Reporting? PACE UNIVERSITY.

Staw, B. M. (1977). Motivation in organizations: Toward synthesis and redirection. See Connolly 1 977.

Sugiyono. (2016). Metode Penelitian Kuantitatif, Kualitatif, dan R\&D. Bandung: Penerbit Alfabeta. 
Sulistiyani, A. T., \& Rosidah. (2018). Manajemen Sumber Daya Manusia "Pendekatan Teoritik dan Praktik Untuk Organisasi Publik" (Cetakan 1). Yogyakarta: Gava Media.

Sunu, P. (1999). Peran Sumber Daya Manusia Dalam Penerapan ISO 9000. Jakarta: Penerbit Grasindo.

Susilawati, \& Sudarno. (2014). Effect of Government Accounting Standards of Quality of Financial Statements and Implications on Local Government Accountability Performance : A Case Study in the Department Pekanbaru. International Journal Of Empirical Finance, 3(5), 243-254.

Susilawati, \& Riana, D. S. (2014). Standar Akuntansi Pemerintahan dan Sistem Pengendalian Intern Sebagai Anteseden Kualitas Laporan Keuangan Pemerintah Daerah. STAR - Study \& Accounting Research, XI(1), 15-32.

Susilo, L. J., \& Kaho, V. R. (2018). Manajemen Risiko (1st ed.). Jakarta: PT Grasindo.

Sutaryo, \& Sinaga, D. (2018). Government Internal Control System Maturity: The Role of Internal Guidance and External Control of Local Government in Indonesia. Jurnal Akuntnasi Dan Investasi, 19(1), 24-35. https://doi.org/10.18196/jai.190189

Suwanda, D. (2015). Factors Affecting Quality of Local Government Financial Statements to Get Unqualified Opinion (WTP) of Audit Board of the Republic of Indonesia (BPK). Research Journal of Finance and Accounting, 6(4), 139-157.

Suwanda, D., Wiratmoko, \& Lindri, I. (2017). Panduan Penerapan "Reviu Laporan Keuangan" Pemerintah Daerah. Bandung: PT Remaja Rosdakarya.

Suwardjono, P. (2010). Accounting Theory: Financial Reporting Engineering (Edition II). Yogyakarta: BPFE.

Suwardjono. (2014). Teori Akuntansi (Perekayasaan Pelaporan Keuangan) (Edisi Keti). Yogyakarta: BPFE.

Suwatno, \& Priansa, D. J. (2016). Manajemen SDM dalam Organisasi Publik dan Bisnis (Cetakan $\mathrm{Ke})$. Bandung: Alfabeta.

Syarifudin, Surasni, N. K., \& Inapty, B. A. (2016). Determinan Kualitas Laporan Keuangan dan Implikasinya terhadap Akuntabilitas Publik (Studi Empiris pada Inspektorat Kab. Lombok Timur, Kabupaten Bima dan Perwakilan BPKP Provinsi NTB). In SNA XIX Lampung. Retrieved from https://sna-iaikapd.or.id

Tambingon, H. N., Yadiati, W., \& Kewo, C. L. (2018). Determinant Factors Influencing the Quality of Financial Reporting Local Government in Indonesia. International Journal of Economics and Financial Issues, 8(2), 262-268.

Tandiontong, M. (2016). Kualitas Audit dan Pengukurannya (Cetakan ke). Bandung: Alfabeta, CV.

Umar, H., \& Nasution, M. I. (2018). Saudi Journal of Business and Management Studies ( SJBMS ) The Influence of the Government Internal Control System and Internal Audit on Corruption Prevention Mediated By Implementation of Actuals-Based Accounting. Saudi Journal of Business and Management Studies (SJBMS), 3(3), 359-372. https://doi.org/10.21276/sjbms.2018.3.3.16

Upabayu, I. P., Mahaputra, R., \& Putra, I. W. (2014). Analisis Faktor-Faktor yang Mempengaruhi Kualitas Informasi Pelaporan Keuangan Pemerintah Daerah. E-Jurnal Akuntansi Universitas Udayana, 8(2), 230-244.

UU Nomor 15 Tahun. Undang-Undang Republik Indonesia Nomor 15 Tahun 2004 Tentang Pemeriksaan Pengelolaan Dan Tanggung Jawab Keuangan Negara, Pub. L. No. Nomor 15 Tahun 2004, 1 (2004). Indonesia.

Watts, R. L., \& Zimmerman, J. L. (1978). Towards a Positive Theory of The Determinan of Accounting Standards. THE ACCOUNTING REVIEW, III(112-134).

Watts, R. L., \& Zimmerman, J. L. (1990). Positive Accounting Theory: A Ten Year Perspective. The Accounting Review, 65(1), 131-156. https://doi.org/10.2307/247880

Wibowo. (2015). Perilaku Dalam Organisasi (Cetakan ke). Jakarta: PT RajaGrafindo Persada.

Wisdom, O., Damilola, E., Inemesit, B., \& Opeyemi, A. (2017). Public sector accounting standards 
and quality of financial reporting : A case of Ogun state government administration in Nigeria. Business and Management Research, 7(December), 76-81.

Yunita, T. A., Tanjung, A. R., \& Anggraini, L. (2015). Pengaruh Penerapan Standar Akuntansi Pemerintahan, Sistem Pengendalian Internal Dan Kompetensi Staf Akuntansi Terhadap Kualitas Laporan Keuangan Pemerintah Daerah (Studi Pada SKPD Kota Dumai). Jom Fekon, 2(2), 1-15.

Yusniar, Darwanis, \& Abdullah, S. (2016). Pengaruh Penerapan Sistem Akuntansi Pemerintahan dan pengendalian Intern Terhadap Good Governance dan Dampaknya Pada Kualitas Laporan Keuangan (Studi Pada SKPA Pemerintah Aceh). Jurnal Magister Akuntansi Pascasarjana Universitas Syiah Kuala, 5(2), 100-115.

Zimmerman, D. H., \& Wieder, D. L. (1977). The Diary "Diary -Interview Method." Urban Life, Vol 5(No. 4), 479-498. 